\title{
MENJAGA STRES DIRI SELAMA PANDEMI (PENGABDIAN MASYARKAAT STIKeS PANTI WALUYA SELAMA PANDEMI COVID-19)
}

\author{
Kristianto Dwi Nugroho ${ }^{1}$, Ucip Sucpito ${ }^{2}$ \\ ${ }^{1,2}$ Program Studi S1 Ners STIKes Panti Waluya Malang \\ Jalan Yulius Usman No 62 \\ e-mail: kristianto.nugroho77@yahoo.co.id
}

\begin{abstract}
ABSTRAK
Wabah COVID-19 pertama kali mungul pada bulan Desember 2019 di kota Wuhan China dan terus menyebar sampai ke seluruh dunia, termasuk Indonesia. Penyebaran wabah COVID-19 yang begitu cepat membuat pemerintah Indonesia menerapkan Pembatasa Sosial Berskala Besar (PSBB). Dampak berantai dari pelaksanaan PSBB dan penyebaran COVID-19 menyebabkan menjadi stressor bagi masyarakat. Beberapa stressor yang muncul dalam masyarakat seperti kekhawatiran karena tertular COVID-19, dampak negatif pandemic terhadap Perekonomina, dampak negatif COVID-19 dalam bidang sosial serta kecemasan dalam berinteraksi. Berbagai macam stressor tersebut harus dikendalikan, salah satunya dengan memberikan pendidikan mengenai majanemen Stres bagi masyarakat. Pemberian pendidikan kesehatan melalui dalam bentuk vidio dan diberikan melalui aplikasi media grup whatsapp. Pemberianpendidikan kesehatan melalui metode video edukasi dan dibagikan kepada masyarakat seperti komunitas gereja, komunitas relawan malang raya dan komunitas dalam keluarga. Pemberian pendidikan kesehatan tersebut mendapatkan respon yang positif. Saat dilakukan evaluasi, 60\% partisipan mennyaksikan vidio tersebut dan $45 \%$ responden memberikan tanggapan positif. Dari evaluasi tersebut, kita memerlukan metode pendidikan kesehatan kepada masyarakat, tetapi melalui media baru untuk mencegah perkumpulan oranng, tetapi seluruh pesan pendidikan kesehatan dapat tersampaikan.
\end{abstract}

\section{Kata Kunci : Pandemi COVID-19; Stresor; Manajemen Stress; Komunitas}

\begin{abstract}
The COVID-19 outbreak first hit in December 2019 in China's Wuhan city and continues to spread to the rest of the world, including Indonesia. The rapid spread of the COVID-19 outbreak led the Indonesian government to implement a Pembatasan Sosial Berskala Besar (PSBB). The chain impact of the implementation of PSBB and the spread of COVID-19 causes stressors for the community. Some stressors that arise in the community such as concerns about contracting COVID-19, the negative impact of pandemics on the Economy, the negative impact of COVID-19 in the social ized field as well as anxiety in interacting. Various kinds of stressors must be controlled, one of which is by providing education about stress management for the community. The provision of health education through in the form of vidio and given through whatsapp group media application. Providing health education through educational video methods and distributed to communities such as church communities, unfortunate volunteer communities and families. The provision of health education received a positive response. During the evaluation, $60 \%$ of participants corrected the video and $45 \%$ of respondents gave a positive response. From these evaluations, we need methods of health education to the public, but through new media to prevent sorority, but the whole message of health education can be conveyed.
\end{abstract}

Key Words- COVID-19 Pandemic; Stresor; Stress Management; Community

\section{PENDAHULUAN}

Sejak ditetapkan mennjadi pandemic global oleh WHO pada tanggal 11 Maret 2020, COVID-19 menjadi isu kesehatan di seluruh dunia. Pandemi virus COVID-19 ini diawali saat ditemukannya pasien penyakit demam dan pernafasan di Wuhan, Cina pada Desember 2019 (WHO, 2020). Wabah tersebut semakin menyebar sampai ke seluruh dunia termasuk Indonesia. 
Gejala COVID-19 yang paling umum adalah demam, batuk kering, dan kelelahan. Gejala lain yang kurang umum dan dapat mempengaruhi beberapa pasien termasuk sakit dan nyeri, hidung tersumbat, sakit kepala, konjungtivitis, sakit tenggorokan, diare, kehilangan rasa atau bau atau ruam pada kulit atau perubahan warna jari tangan atau kaki. Gejala-gejala ini biasanya ringan dan mulai secara bertahap. Beberapa orang menjadi terinfeksi tetapi hanya memiliki gejala yang sangat ringan (WHO, 2020).

Karena semakin bertambahnya kasus COVID-19 di seluruh dunia, maka dilakukan pembatasan aktifitas. Indonesia juga melakukan melakukan pembatasan serupa yang disebut Pembatasan Sosial Berskala Besar (PSBB). Penerapan PSBB termuat dalam Peraturan Presiden nomor 21 tahun 2020 menyatakan bahwa akan dilaksanakan peliuran sekolah, tempat kerja, kegiatan keagamaan dan pembatasan kegiatan umum (Presiden Republik Indonesia, 2020).

Kegiatan PSBB secara langsung ataupun tidak langsung berdampak pada seluruh sektor kehidupam masyarakat, baik segi budaya hingga ekonomi. Menurunnya aktifitas masyarakat karena kegaitan pembatasan sosial mengakibatkan penurunan daya beli, dan sampai penutupan pusat-pusat perekomomian masyarakat. Dampak tersebut mangakibatkan pemutusan kerja bagi masyarakat. Rangkaian hal tersebut menjadi stresos yang sangat besar bagi kebanyakan masyaraka perekonomian menengah kebawah. Ditambah dengan stressor dari ketakutan warga tertular virus COVID-19 dan terbantasnya aktifitas masyarakat karena diberlakukannya PSBB mengakibatkan tambahan stressor bagi masyarakat (Praveena, Gangadhar and Ratnam, 2020).

Benyaknya stressor yang muncul dapat mempengaruhi sistem imun di masyarakat. Manajemen stress yang baik bagi masyarakt diperlukan untuk mengelola stress dalam keadaan pandemic COVID-19 seperti saat ini(Newman and Lattouf, 2020). Peran perawat untuk melalukan pendidikan kesehatan dalam mengelola stress masyarakat sangat diperlukan supaya masyarakat lebih tahan saat mengalami keadan buruk seperti saat ini.

\section{METODE}

Pengabdian kepada masyarakat yang dilakukan oleh pengabdi menggunakan metode jarak jauh. Pengabdi menyiapkan sebuah vidio yang berisi pendidikan kesehatan mengenai manajemen stress. Vidio tersebut disusun menggunakan aplikasi pembuatan vidio davici Resolve 19 dan pembuatan vidio onlie www.animaker.com. Vidio yang dibuat berdurasi 3 menit 20 detik.

Setelah vidio disusun, vidio di upload melalui media sosial www.youtube.com dan Instagram. Vidio dimasukkan pada chanel LPPM STIKes Panti Waluya Malang.

Pengabdin menghubungi kelompok-kelompok penanggung jawab setiap grup dan memohon persetujuan dalam melakakukan pendidikan kesehatan melalui vidio. Setelah diberikan izin secara lisan ataupun melalui pesan instan whatsapp, pengabdi melakukan share kepada grup whatsap tiap kelompok. Ada beberapa grup wahtsap yang dilakukan share seperti grup gereja GPdI Gloria, Grub Potensi Relawan Malang Raya, Grup PO HART SAR Malang Raya, Grup Keluarga dan beberapa grup Keluarga.Setelah pengabdi membagikan video tersebut, pengabdi melakukan evaluasi menggunakan google form. 


\section{HASIL dan PEMBAHASAN}

Keterbatasan ini memerlukan pendidikan kesehatna kepada masyarakat yang lebih interaktif dan lebih mudah diterima masyarakat sambil mengurangi pengumpulan masa. Salah satu caranya menggunakan metode daring.

Metode daring melalui vidio pendidikan kesehatan manjemen stress melalui beberapa metode seperti berikut:

1. Mengenali Pemicu Stress

Tahap awal dalam manajemen stress dengan mengenali penyebab stress. Setiap orang memiliki stressor yang berbeda-beda. Kenali pemicu stress sangat diperlukan untuk menentukan tindakan lanjutan dalam menangani stress (Clompus and Albarran, 2016).

2. Hindari Pemicu Stress

Setelah mengenali penyebab stress, maka diarahkan untuk menghidari pemicu stress. Menghindari bisa dilakukan dengan melakukan teknik pengalihan ataupun mencari aktifitas lain untuk menghidari pemicu stress(Turner, 2014).

3. Ubah Kebiasan Pemicu Stress

Jika tidak memungkinan untuk menghindari pemicu stress, alternative lain dengan mengubah kebiasaan yang muncul. Melakukan kegiatan sehari-hari menggunakan ururtan yang berbeda dan mengubah kebiasaan yang dilakukan dapat menjadikan stress menurun (Robertson and Cooper, 2013).

4. Berolahraga Teratur
Kebiasaan
olahraga
dapat meningkatkan mood. Membiasakan untuk olahraga merupakan alternative menurunkan stress serta dapat meningkatkan sistem kekebalan tubuh.

5. Adakan Waktu Bersantai

Kebiasaan untuk bersantai sejenak merupakan solusi untuk menenangkan pikiran. Bersantai ditengah kesibukan dapat menjadi alternative

mengurangi

stress(Robertson and Cooper, 2013).

6. Melakukan Sosialisasi

Manusia pada dasarnya merupakan makhuk sosial yang harus bersosialisasi satu dengan yang lainnya. Pandemi COVID-19 menjadikan masyarakat melakukan pembatasan dalam bersosialisasi. Melakukan sosialisasi dengan metode daring seperti melalui media sosial, ataupun aplikasi vidio call dapat menjadi alternative (Bohström, Carlström and Sjöström, 2016).

Pengabdian kepada masyarkaakat yang dilakukan dalam komunitas yang menyasar di malang raya. Dalam melakukan pengabdian kepada masyarakat disusun beberapa pertanyaan seperti sebagai berikut:

1. Apakah anda mengalami stress karena pandemic COVID-19?

2. Apakah anda memerlukan manajemen stress selama masa pandemic COVID-19?

3. Apakah anda menyaksikan vido dari awal sampai akhir?

4. Anda tidak mendapat informasi apapun dari vidio tersebut.

5. Anda dapat melakukan tahapantahapan manajemen stress

6. Vidio tersebut milikiki dampak positif bagi anda.

Berikut merupakan tabel hasil evaluasi tindakan pengabdian kepada masyarakat yang dilakukan oleh pengabdi:

Tabel 1.Jumlah yang mengisi lembar evaluasi

\begin{tabular}{lll}
\hline Kelompok & Jumlah & $\begin{array}{l}\text { Jml Mengisi } \\
\text { Kuesioner }\end{array}$ \\
\hline $\begin{array}{l}\text { Grup Gereja GPdI } \\
\text { Gloria }\end{array}$ & 60 & $42(70 \%)$ \\
$\begin{array}{l}\text { Grup Potensi } \\
\text { Relawan Malang }\end{array}$ & 80 & $58(72,5 \%)$ \\
$\begin{array}{l}\text { Raya } \\
\text { Grup PO HART }\end{array}$ & 42 & $26(61,9 \%)$ \\
$\begin{array}{l}\text { SAR Malang Raya } \\
\text { Grup Keluarga }\end{array}$ & 36 & $32(88 \%)$ \\
\hline
\end{tabular}


Tabel 1 menunjukkan bahwa banyak responden yang tertarik dengan pendidikan kesehatan berupa video manajemen stress. Hal tersebut tertera dari banyya responden yang mengisi kuesioner. Dengan mengisinya kuesioner membuktikan bahwa responden melihat video dan menanggapi seluruh proses pendidikan kesehatan yang biberikan.

Tabel 2. Evaluasi Pemahaman Isi Pengabdian

\begin{tabular}{lll}
\hline $\begin{array}{l}\text { No } \\
\text { Pertanyaan }\end{array}$ & Jawaban & Prosentase \\
\hline 1 & Ya & $62 \%$ \\
& Tidak & $38 \%$ \\
2 & Ya & $86 \%$ \\
& Tidak & $14 \%$ \\
3 & Ya & $100 \%$ \\
& Tidak & $0 \%$ \\
4 & Ya & $8 \%$ \\
& Tidak & $92 \%$ \\
5 & Ya & $88 \%$ \\
& Tidak & $12 \%$ \\
6 & Ya & $96 \%$ \\
& Tidak & $4 \%$ \\
\hline
\end{tabular}

Tabel 2 menunjukkan jawaban dari responden mengenai kegiatan pendidikan berupa manajemen stress bagi masyarkaat. Dari tabel tersebut menunjukkan bahwa sebagian besar respinden $(62 \%)$ mengalami stress karena pandemic COVID-19. Pandemi ini mengakibatkan berbagai dampak negative sehingga menjadi stressor bagi masyarkaat. Pernyataan kedua menunjukkan apakah responden memerlukan manajemen stress. Responden menyadari perlunya manajemen stress dikarenakan berbagai tresor yang muncul terutama disaan pandemic COVID-19.Pernyataan ketiga menunjukan bahwa $100 \%$ responden menyaksikan video pendidikan kesehatan manajemen stress. Dalam penyataan keempat menunjukkan bahwa banyak responden mendapatkan informasi dari video tersebut.

Pernyataan kelima menunjukkan bahwa sebanyak $88 \%$ responden dapat memahami dam melaksanakan berbagai tahapan manajemen stress. Dalam pernyataan keenam menunjukkan bahwa 96\% responden berpendapat bahwa vidio tersebut memiliki dampak positif bagi responden.

Pembahasan tersebut menunjukan bahwa pendidikan kesehatan menggunakan video efektif dapat meningkatkan pengetahuan masyarakat. Dikarenakan pendidikan secara langsung dengan menumpulkan masyarakat dan tatap muka secara langsung tidak dianjurkan karena masih masa pandemic COVID-19. Sehingga pendidikan kesehatan alternatif perlu dipersiapkan. Pendidikan kesehatan dengan menggunakan metode jarak jauh perlu ditingkatkan dengan berbagai metode dangan memanfaatkan teknologi informasi.

\section{KESIMPULAN DAN SARAN}

Manajemen stress bagi masyarkat ditengah pandemic COVID-19 diperlukan bagi masyarakat. Pendidikan tersebut dilakukan menggunakan cara alternatif seperti vidio ataupun pemanfaatan teknologi informasi lainnya. Pengembangan pendidikan kesehatan dapat dilakukan menggunakan metode vidio alternatif lain supaya masyarakat tetap teredukasi meskipun tidak dapat dapat melakukan perkumpulan pendidikan secara konvensional. Pengabdi diharapkan Menyusun media pengabdian kepada masyarakat yang lebih inovatif ditengan pandemic COVID-19. Inovasi pengabdian diharpakan menjadi solusi bagi masyarkaat.

\section{DAFTAR PUSTAKA}

Bohström, D., Carlström, E. and Sjöström, N. (2016) 'Managing stress in prehospital care: Strategies used by ambulance nurses.', International emergency nursing, 32, pp. 6-11. doi: 10.1016/j.ienj.2016.08.004. 
Clompus, S. R. and Albarran, J. W. (2016) 'Exploring the nature of resilience in paramedic practice: A psycho-social study', International Emergency Nursing. Elsevier Ltd, 28, pp. 1-7. doi: 10.1016/j.ienj.2015.11.006.

Newman, N. A. and Lattouf, O. M. (2020) 'Coalition for medical education-A call to action: A proposition to adapt clinical medical education to meet the needs of students and other healthcare learners during COVID-19', Journal of Cardiac Surgery, 35(6), pp. 1174-1175. doi: 10.1111/jocs.14590.

Praveena, P. B. G., Gangadhar, M. and Ratnam, K. V. (2020) 'International Journal of Medical Science and Dental Research Effectiveness of e- learning among college students on knowledge regarding COVID - 19', 03(02), pp. 718.

Presiden Republik Indonesia (2020) Peraturan Pemerintah Nomor 21 Tahun 2020 tentang Pembatasan Sosial Berskala Besar Dalam Rangka Percepatan Penanganan Coronavirus Disease 2019/COVID-19. Jakarta: Republik Indonesia.

Robertson, I. and Cooper, C. L. (2013) 'Resilience', Stress and Health, 29, pp. 175-176. doi: 10.1002/smi.2512.

Turner, S. B. (2014) 'The resilient nurse: An emerging concept', Nurse Leader. Mosby, Inc., 12(6), pp. 71-90. doi: 10.1016/j.mnl.2014.03.013.

WHO (2020) Coronavirus disease (COVID-19) pandemic, Word Health Organization. Available at: https://www.who.int/emergencies/diseas es/novel-coronavirus-2019/advice-forpublic. 